\title{
Gender and Electoral Representation in Ireland
}

\section{Claire McGing and Timothy J. White}

\section{(2) OpenEdition \\ 1 Journals}

\section{Electronic version}

URL: https://journals.openedition.org/etudesirlandaises/3134

DOI: 10.4000/etudesirlandaises.3134

ISSN: 2259-8863

\section{Publisher}

Presses universitaires de Caen

\section{Printed version}

Date of publication: 30 October 2012

Number of pages: $33-48$

ISBN: 978-7535-2158-2

ISSN: 0183-973X

\section{Electronic reference}

Claire McGing and Timothy J. White, "Gender and Electoral Representation in Ireland", Études irlandaises [Online], 37-2 | 2012, Online since 30 October 2014, connection on 27 July 2022. URL: http://journals.openedition.org/etudesirlandaises/3134 ; DOl: https://doi.org/10.4000/ etudesirlandaises.3134

This text was automatically generated on 27 July 2022.

\section{(c) (i) (9) (2)}

Creative Commons - Attribution-NonCommercial-ShareAlike 4.0 International - CC BY-NC-SA 4.0 https://creativecommons.org/licenses/by-nc-sa/4.0/ 


\title{
Gender and Electoral Representation in Ireland
}

\author{
Claire McGing and Timothy J. White
}

\section{Gender and Electoral Representation in Ireland}

1 One of the fundamental assumptions of democracy is that citizens are equal, but do democracies guarantee equality of all citizens, including women? One of the historic challenges for equality in democracies is that women are less likely to serve as elected representatives ${ }^{2}$. Much of the literature has focused on the need for a "critical mass" of at least 30 per cent women representatives in parliament so that legislation and government policy will take into account women's interests and issues ${ }^{3}$. Some feminist scholars have concluded there is little evidence that a critical mass of elected women will transform the political process and instead advise the importance of "critical actors" ${ }^{4}$. These are representatives who initiate policy proposals on their own and encourage others to promote policies for women. They may do so even when women comprise a minority in parliament (and in some cases may even be men). Mansbridge stresses that some women representatives act as "surrogate" representatives for females who live beyond the borders of their geographically defined constituencies, on the basis of a shared gender identity. Far from requiring an increase in the presence of women in parliament, this form of representation might work best in the context of low numbers. To quote Mansbridge, "feelings of responsibility for constituents outside one's district grow even stronger when the legislature includes few, or disproportionately few, representatives of the group in question ${ }^{5 "}$. A smaller body of research suggests that women politicians bring a distinct approach to their constituency work. Survey research shows they devote more time to casework helping individuals with their problems $s^{6}$. Some scholars believe the constituency provides an ideal environment for women representatives to "act for women in substantive terms. Gender-conscious female legislators feel women constituents better identify with them and access them in greater numbers than they would with a male representative ${ }^{7 "}$. 
2 Like much of the rest of the world, electoral politics in Ireland is a highly masculine realm. In total, only 91 women deputies have been elected since the foundation of the State in $1922^{\circ}$. The state currently has one of the worst parliamentary gender imbalances in the democratic world. Following the 2011 general election, women hold 25 seats out of 166 (15.1 per cent) in the $31^{\text {st }}$ Dáil (Irish Parliament). Although low, this is a record high for the number of women elected in an Irish general election. Progress has been extremely slow in improving women's representation in recent years. Significant improvement was made between 1977 and 1992 where the percentage of female representatives increased from 4 to 12 per cent. However, progress since then has remained generally static, with only five more women elected in 2011 than had been in the parliament in 1992. Ireland currently places $87^{\text {th }}$ in the world rankings of women in national parliaments and below the European ( 23 per cent) and global ( 20 per cent) averages 9 . What has caused the electoral underrepresentation of women in Ireland?

\section{Barriers to Women's Electoral Representation and the 2011 Irish General Election}

3 The earliest study of female representation in Ireland attributed low levels of women's representation to the combined effect of cultural forces and electoral institutions ${ }^{10}$. Since then, scholars have tended to emphasize either cultural factors or institutional factors in their research. Numerous scholars have pointed to cultural or ideological factors as the principal obstacles to the election of women ${ }^{11}$. The scholarship in this area often focuses on the effects of discrimination and bias against female candidates and office holders, as well as the socialization of women to adopt gender roles that limit them to the private sphere ${ }^{12}$. Indeed, a substantial number of empirical studies link women's work outside of the home to higher levels of female representation and participation ${ }^{13}$. Feminist scholars have argued that the patriarchal nature of Irish society has historically minimized and marginalized women's role in society, limiting them to the private sphere of home life and excluding them from politics ${ }^{14}$. Indeed, the domestic and maternal role of women is constitutionally guaranteed. Enacted in 1937, and influenced by the highly dominant Roman Catholic Church, the Irish Constitution draws no distinction between the concepts of womanhood and motherhood, fusing them as one. Articles 41.2.1 and 41.2.2 state (as they still do today):

The State recognizes that, by her life within the home, woman gives to the State a support without which the common good cannot be achieved.

The State shall, therefore, endeavour to ensure that mothers shall not be obliged by economic necessity to engage in Labor to the neglect of their duties in the home.

Although cultural factors may help explain the historically low numbers of women elected to the Dáil, they cannot explain why earlier increases in female representation have not been extended. Irish women gained the franchise comparatively early, a factor normally associated with higher levels of women's representation ${ }^{15}$. In addition, the number of women in the Irish workforce and the number of married women working outside the home has risen substantially in recent years ${ }^{16}$. Thus, one would expect more women embarking on political careers just as they have increasingly entered other professions. In what was dubbed the "Celtic Tiger" Ireland experienced phenomenal rates of economic growth between the mid-1990s and early 2000 s. 
Although given little recognition in academic and popular accounts of this period, the increasing numbers of married women in the workforce no doubt contributed significantly to this growth, so much so that O'Connell argues that the term Celtic Tiger "had misconstrued the gender of the animal ${ }^{17 "}$. Capitalism required cheap Labor to function and, often taking up part-time jobs to maintain a balance between the spheres of work and care, Irish women provided it. 60 per cent of women were working outside the home in 2007, surpassing the European average ${ }^{18}$. In this light it is somewhat puzzling that the expansion of economic and social opportunities available to women in Ireland has not led to higher levels of female political representation. The slow growth in women's representation that Ireland has experienced over the last two decades cannot be explained by cultural factors alone.

Scholars are divided as to whether the Irish electorate is biased against women candidates. Some contend that female candidates are subject to discrimination from voters ${ }^{19}$. However, two recent studies found no evidence of gender bias in the Irish electorate once variables such as partisan affiliation and previous political experience are considered and controlled for ${ }^{20}$.

Increasingly, scholars have turned to institutional explanations for the lack of women's representation in numerous national parliaments. A number of institutional obstacles have been identified inhibiting greater female representation. For example, scholars have found that women candidates are at a disadvantage in political systems which favor incumbent candidates over challenger candidates. Because most incumbents are men, female candidates are unable to take advantage of the increased name recognition, political support, and resources available to their incumbent male opponents. Incumbency continues to be advantageous in the Irish political context and thus a significant obstacle to increasing women's representation ${ }^{21}$.

7 Research also suggests that the political status and representation of women is linked to other institutional factors such as the electoral system and whether or not women played a critical role in achieving democracy ${ }^{22}$. Fitzgerald, for instance, contends that proportional representation by single transferable vote electoral systems (STV) encourage candidates and elected representatives to focus excessively on local issues and constituent service (rather than national issues and party platforms), which favors the election of candidates from certain types of professions ${ }^{23}$. It is of little surprise that Irish politicians have often come from occupational backgrounds in teaching or law, or held even more localized jobs such as undertakers, shopkeepers and publicans ${ }^{24}$. As well as facilitating economic independence and flexibility of time, such "brokerage" occupations easily allow them to develop a strong local profile. This phenomenon too is gendered. Although a number of women have worked in teaching and law prior to entering politics, men have accounted for the majority of politicians who have come from the local business sector. This suggests that women have had to use educational achievements to gain additional credibility at the candidate selection stage in a way that men have not.

8 Despite some concerns, the Irish STV system is generally viewed as more friendly to the election of women than a first-past-the-post or majoritarian election system ${ }^{25}$. The principal benefit of STV in the Irish context is that multimember districts allow historically underrepresented minorities and non-incumbents (i.e. women) to win seats that they would not be able to win in single-member district elections. This is especially true in constituencies where popular established politicians can transfer votes to 
members of the same political party ${ }^{26}$. Under STV, parties can spread their vote to maximize their number of seats ${ }^{27}$, enabling female challengers to win election despite the fact that they did not receive as large a share of the first preference votes as male incumbents. Thus, the threshold effect suggests that the larger the district magnitude, the more likely minority candidates (e.g., women, independents, members of small parties) will be selected and win a seat ${ }^{28}$.

of all the major Irish political parties in the 2011 Irish general election, Fine Gael most closely conformed to the expectation of the literature on gender and district magnitude. As district magnitude increased, the percentage of female candidates increased significantly. Women comprised just 9 per cent of Fine Gael candidates in 3seat constituencies, but 15 per cent and 22 per cent of candidates in 4 and 5-seat constituencies were women. Fianna Fáil's selection of women candidates were more evenly spread throughout the various constituency sizes, although they did make up a slightly higher percentage of their candidates in 4 and 5-seat constituencies. Half of all Labor women candidates stood for election in 4-seat constituencies, making up 31 per cent of those candidates. Females actually comprised a higher percentage of Labor candidates in 3-seat (26 per cent) as opposed to 5 -seat constituencies (20 per cent). Green Party women candidates were more likely to contest 3-seat constituencies. Constituency size appears to have played a factor in Sinn Féin's candidacy strategy with women making up a considerably lower percentage of their candidates in 3-seat constituencies ( 7 per cent) as opposed to 5-seat constituencies (36 per cent). Overall, women accounted for 14 per cent of party candidates in constituencies with 3 seats, 19 per cent of those with 4 seats and 22 per cent of those with 5 seats. At least in terms of candidates that competed in the 2011 Irish general election, it appears that parties are more likely to field more female candidates in districts or constituencies where more representatives are elected.

Some of the most recent research has gone beyond electoral system and increasingly focused on the institutional process of getting women on the ballot. Sanbonmatsu emphasizes the role of the recruitment as a critical factor to expand the number of female candidates and elected officials ${ }^{29}$. If women could be recruited at younger ages to run for local office and sustain their political careers while they raise their families, we would expect a growing percentage of successful female Dáil candidates ${ }^{30}$. National party elites in Ireland have much less control over candidate selection than in other Proportional Representation List systems. With some exceptions (as will be explored below), candidates are usually selected at a constituency level by card-carrying party members. Historically, local connections have been the determining factor for candidate success and party leaders have been constrained in promoting significant numbers of female candidates by the need to recruit candidates who are, first-andforemost, attractive to voters ${ }^{31}$. Political experience, name recognition, and reputation in the local area equate to electability, and these are the key attributes which local selectors look for when selecting candidates. Weeks found that in the 2007 general election, party strategists dismissed both gender and age in determining who would be successful candidates but stressed the importance of electability ${ }^{32}$. Would-be Irish deputies commonly first "cut their teeth" in local politics, allowing them to develop support networks, gain name recognition, learn the rules of the political game, and build up a relationship with constituents. Like national politics, however, local politics 
in Ireland is still dominated by men. Just 17 per cent of councillors at present are female.

11 The candidate selection process is thus now seen as most crucial to improving gender representation ${ }^{33}$. The norm in liberal democracies is for political parties to act as "gatekeepers" in that they recruit election candidates (bar those that decide to run as independents, although Chapman argues that independent candidates often emerge from partisan and/or farming or business networks, acting to further disadvantage women ${ }^{34}$ ) and, according to Lovenduski, this ensures that party masculinity is mapped onto political representation ${ }^{35}$. Scholars have employed a model of "supply and demand" to explain party recruitment of candidates ${ }^{36}$. Demand is influenced by the political opportunity structure in a given constituency, such as the number of seat vacancies as well as the selector's own attitudes and their perceptions of the "type" of candidates voters prefer. The demographic homogeneity of parliament may influence the views of the selectorate. An inbuilt bias may exist towards running candidates who most closely resemble the male party elite. Supply-side explanations, on the other hand, suggest that the outcome reflects the supply of applicants wishing to pursue a career in politics. This is conditioned by the availability (or lack) of resources (such political experience, time, funds and networks) and motivational factors (interest, confidence and ambition). As a result, party leaders frequently say that they would love to have run more women but "not enough came forward".

12 Studies of political recruitment show the importance of active party membership as a formal and/or informal requirement in enhancing the chances of an aspirant being successful in the selection process ${ }^{37}$. In systems of decentralized candidate selection such as Ireland, longtime party members can develop a strong network of fellow party activists, especially those from their own local branch, who will support them at the convention stage and mobilise other members to do the same. Party membership figures can therefore provide some initial insights into the lack of women in electoral politics. Contrary to what some believe women are present in the local echelons of Irish political parties, although this does not nearly match their presence on party tickets: women currently account for 42 per cent of the membership of Fine Gael, 37 per cent of Labor, 34 per cent of Fianna Fáil and 25 per cent of Sinn Féin ${ }^{38}$. These figures illustrate that aspiring women lack the local networks required to rise up from the membership ranks to the ballot paper. The gender gap is particularly large for Fine Gael and Fianna Fáil, who each ran 15 per cent female candidates in the 2011 election. Why is this so? Research shows the resources required to successfully nurture a political base: networks (as already mentioned), funds and time ${ }^{39}$. Given the persistent sexual division of care in Irish society, women are less likely to possess these types of capital to the same extent as men. Mean hourly earnings for Irish male employees in 2009 were $€ 23.63$ and $€ 20.61$ for females, representing an unadjusted gender pay gap of 12.8 per cent ${ }^{40}$. With less cash at their disposal to mount an election campaign (and perhaps even an initial selection campaign), women may hesitate to seek a nomination to run in the first place ${ }^{41}$. "Time poverty" might prove an additional barrier to women. Research undertaken by the National Women's Council of Ireland (NWCI) in 2009 revealed that over the course of a week, Irish women spend a fifth of their day on average engaged in care and domestic work, three times as much as men $\mathrm{do}^{42}$. Female party members may, therefore, have less time to devote to local support-building activities. The same barriers hold true for potential independent women candidates. 
13 A further analysis should scrutinize the selection process in even more detail. For example, anecdotal evidence suggests female aspirants do not receive as much support at selection conventions from fellow women party members as one might expect. On the basis of interviews carried out with women who contested and lost conventions for the 2011 general election, McGing shows that female party activists, just like their male counterparts, often rally their support behind their own local convention candidate, regardless of gender ${ }^{43}$. Considering the importance of geography and local ties in the Irish electoral process, this finding is hardly surprising. More often than not, this wellnetworked convention candidate will tend to be male, perpetuating the masculine cycle of the selection process.

Of the 566 candidates that stood in the 2011 election, a mere 86 ( 15.2 per cent) were women. While numerically there were four more female candidates in 2011 compared to 2007 , the percentage of women candidates actually decreased by 2.2 per cent since 2007. In fact, despite the heightened attention paid to the gender imbalance in Irish politics, the percentage of female candidates in 2011 was lower than in the previous four general elections. 39 out of 43 constituencies had at least one woman candidate in 2011. Voters in four constituencies - Cork South-West, Kildare South, Limerick and Roscommon-South Leitrim - were presented with an all-male ballot paper. A more negative picture emerges regarding the selection of women candidates when one considers the number of female candidates that ran for one of the five main political parties. Strikingly, there were nine constituencies (just over a fifth of the total) in which no women were selected to run at all for Fianna Fáil, Fine Gael, Labor, Sinn Féin or the Greens.

Political parties varied in terms of the percentage of female candidates that were selected to run in 2011, and only two parties saw an increase in the number of women candidates since 2007. Despite running a notably larger number of candidates, Fine Gael raised its number of woman candidates by only one. Labor, on the other hand, took more of an advantage in its rising tide of popularity, with aspiring women benefiting from the party running considerably more multiple candidate tickets than it had in the past. Fianna Fáil ran less candidates in this election, but marginally increased its percentage of women candidates overall. Both Sinn Féin and the Greens ran fewer female candidates. Women made up a quarter of the candidates that ran for the various political affiliations under the United Left Alliance (ULA) umbrella group. Under a tenth of independent candidates were women.

16 Why were so few women selected to run in 2011? Was the imbalance due to a lack of supply, a lack of demand, or the interaction of both? Despite a growing body of literature on women and Irish politics, no large scale study has of yet examined the selection process and its implications for gender representation. How many women go forward to contest selection conventions? Are they as successful as men when they do? This type of data is not easily available and is extremely time-consuming to collect. In an attempt to piece the puzzle together, information on the 2011 convention process in Fianna Fáil, Fine Gael and Labor was gathered from various sources, including local newspapers, social media outlets (Twitter and Facebook), online political forums, election candidates, political representatives, local party activists, and party headquarters $(\mathrm{HQ})^{44}$.

17 Of the 114 formally nominated to contest Fianna Fáil conventions, only 25 (22 per cent) were women. According to a spokesperson at $\mathrm{HQ}$, "a number of the women nominated 
would have been selected had they allowed their names to go forward ${ }^{45}$ ". In many cases the nominee declined to push for selection, often because only incumbents would be running (in the end 65 per cent of Fianna Fáil candidates were incumbents) or because they felt it was not in their best interests to run in this particular contest. As the senior government party for three consecutive terms, polls in advance of the election showed that Fianna Fáil was facing an electoral meltdown as a result of the economic collapse. Consequently, the party played it "safe" and ran few new candidates. Of the women who did contest for a nomination, just two were defeated at convention. These were Cllr. Mary Hoade in Galway East and Sharon Keogan in Meath East (who subsequently ran as an independent, but failed to win a seat). Both were mainly disadvantaged by geographical considerations. In the end, women accounted for approximately 14 per cent of aspirants that were put to Fianna Fáil members. 83 per cent were successful in gaining a place on the ticket, just marginally less than men at 85 per cent.

Women accounted for approximately 18 per cent of all those that contested Fine Gael selection conventions. 58.5 per cent of male nominees and 50 per cent of female nominees were successful, suggesting a slight bias amongst the local selectorate in favor of male candidates. A gender-related controversy arose as a result of the Fine Gael selections in Dun Laoghaire. The incumbent deputy, Sean Barrett, once again contested a nomination as did Councillors John Bailey, Marie Baker, Mary Mitchell O'Connor and Barry Ward. While Barrett topped the poll, Ward and Mitchell O'Connor came second and third respectively. However, a directive sent by party headquarters was read out after the convention vote was taken, instructing members to select just one male and one female candidate. Mitchell o'Connor was placed on the ticket as opposed to Ward. According to media reports, a number of Monkstown Fine Gael branch members that had supported Ward felt "disenfranchised" and believed that the selection process had been undemocratic. However, the Dublin director for Fine Gael, Terry Murphy, denied this and stated that the decision had been reached as part of a party commitment to increasing the number of women candidates ${ }^{46}$. This was the only gender directive sent out by party $\mathrm{HQ}$. By contrast, eight constituency organizations were given geographical selection criteria by Fine Gael ahead of the convention vote, illustrating the importance placed on spatial vote-management.

of the 86 nominees that contested Labor Party conventions across the country, only 24 (28 per cent) were female. Strikingly, no women were nominated to contest 22 conventions (just over half of the total number), while no men were nominated to contest four. Vast numbers of rural conventions, areas where the Labor vote is traditionally much weaker, went uncontested by women. The sole Labor nominee in two constituencies was a woman, Councillor Marie Moloney in Kerry South and Senator Phil Prendergast in Tipperary South. Two women battled it out for a nomination in Meath West and Sligo-North Leitrim. Councillor Jenny McHugh beat Councillor Tracy McElhinney to run in Meath West. The process was more contentious in Sligo-North Leitrim when Councillor Veronica Cawley, who was elected Mayor of sligo in 2008, and Susan O'Keffe, an investigative journalist and unsuccessful Labor candidate in the 2009 European elections, tied at the convention with 71 votes each. After a lengthy review of both candidates, the Executive Council decided to put O'Keffe forward as the candidate, angering a number of supporters in the Cawley camp ${ }^{47}$. Cawley subsequently ran as an independent candidate. In the end, neither of the women won a seat in the election. On the whole, aspiring Labor women were considerably less successful at the selection 
stage than their male counterparts. 47 men and 16 women were selected to run, representing success rates of 76 per cent and 67 per cent respectively.

Overall, the dearth of women candidates is largely explained by their absence at the selection stage. This suggests that supply-side factors are important: not enough women are putting themselves forward as potential candidates because they do not possess the resources to do so. But these figures only tell half the story. As we have seen, when women did contest conventions for Fianna Fáil, Fine Gael and Labor, they were statistically less likely than men to be selected. Although further research is required to tease out potentially important variables (such as incumbency, local political experience, and so on), our findings do suggest a slight bias amongst local selectorates in favour of male candidates, at least at an aggregate level. In turn, if women think they are less likely to attain a nomination, they might be hesitant to put themselves forward.

21 It is more difficult to examine the role of demand-side factors in inhibiting gender representation. For instance, if an electoral opportunity presents itself, are parties more likely to approach a man than a woman to run? Although party candidates are usually selected at a local level, HQ in all parties hold the power to balance tickets by adding further candidates and could therefore use this function to try and facilitate a higher percentage of women. This provides one way to test for the level of demand for female candidates. While the larger political parties did take advantage of this power for their 2011 selections, rarely did they use it to achieve a better demographic balance of candidates, in terms of gender or otherwise, with geographical considerations usually the main reasoning behind their choice. Of the 28 candidates added by party $\mathrm{HQ}$, only five (18 per cent) of these were female. Fianna Fáil added a male and a female candidate. The woman was Lisa Chambers, a 24 year old first time candidate and Chairperson of the Castlebar Town Branch, who was selected as Deputy Dara Calleary's running mate in Mayo. Despite Fine Gael making 18 later additions, only two (11 per cent) of these were women. These were sitting councillors Cáit Keane in Dublin SouthWest, who ran alongside the sitting deputy Brian Hayes, and Hildegarde Naughton in Galway West, who ran on a four candidate ticket. Two (25 per cent) of the eight candidates selected later on by Labor were female. These were Mary Moran in Louth and Lorraine Higgins in Galway East, both added as running mates to a sitting male councillor. Moran had never before stood for election while Higgins had run unsuccessfully as an independent candidate in the 2009 local elections.

\section{Shocking the System: The Proposed Gender Quota Legislation}

Lovenduski argues that there are three strategies available to actors (political parties and governments) who wish to see an increase in the presence of women in political assemblies - equality rhetoric, equality promotion, and equality guarantees.

Equality rhetoric is the public acceptance of women's claims and examples can be found in party manifestos and in the speeches and writings of political leaders. With elites publicly acknowledging that the lack of women in decision-making is a problem that needs to be addressed, "an equality discourse emerges that may increase the common ground for action ${ }^{48}$. Although equality rhetoric alone falls short of implementing measures to redress the historic underrepresentation of women, it can make strategies 
for change seem possible. Equality promotion, on the other hand, is the introduction of "soft" measures to bring more females into politics. Examples include setting targets for the presence of women in future, awareness raising campaigns, supports for politically aspiring women such as training, mentoring programs, networks and financial assistance, funding women's advocacy groups and including them in consultations, and governments signing international treaties on women's equality. By offering encouragement and attempting to break down some of the barriers they may face, promotion strategies are directed primarily at the supply of potential women candidates.

Irish political parties have made use of both equality rhetoric and equality promotion in the past, to varying degrees of success. It is not unusual for party leaders to make reference to enhancing women's political participation in important speeches or for parties to include sections relating to this in their manifestos. For example, upon taking over the leadership of Fianna Fáil in 2011, Micheál Martin asserted in his first official speech that the party was open to more women and young members. In addition, all parties have set themselves targets for female candidates in the past, but these are rarely met. If they are, it tends to be for weaker offices in local government. They are less inclined to introduce gender aspirations for selections at national elections.

The 2009 local elections provide an illustrative example. In spite of hostility from local branches, the central Fianna Fáil authorities took a leading role in the selection process. Conventions were cancelled and aspirant candidates were instead interviewed. Prior to selections, the party announced that it would interview more young people and females around the country. Despite this, Fianna Fáil ended up running just 17 per cent women, an increase of just 2 per cent since 2004. Labor and Sinn Féin both proposed targets to run at least 30 per cent females candidates, while the Green Party were even more ambitious with a 40 per cent aspiration. While the percentage of women selected by Labor (23 per cent) and Sinn Féin ( 23 per cent) did improve on their 2004 levels, the proportion run by the Green Party ( 22 per cent) actually declined. Without sanctions for non-compliance, there is often little initiative for local party organizations to meet targets. The Fine Gael Executive Council set a gender target for town council selections in 2004 and continued it in 2009, but proposed no targets for selections to the more powerful city and county councils. As far as possible, at least one woman candidate was selected at each convention. Research by Dinan shows this measure was very successful in leading to higher rates of local female representation ${ }^{49}$. Recognizing that political parties are the main gatekeepers to women's representation, equality guarantees focus on the demand for female candidates. Electoral gender quotas are an example of such a measure and ensure that a certain percentage of women are nominated to run or are elected. Quotas are often regarded as a "fast track" strategy for political gender balance, as opposed to an "incremental track" strategy which perceives that equal representation should be allowed to run its natural course ${ }^{50}$. Although controversial for reasons that will be explored below, over 100 countries worldwide have introduced some form of gender quota.

In December 2011, the Irish Minister for the Environment, Community and Local Government, Mr. Phil Hogan T.D., proposed new legislation whereby Irish political parties will have to implement a gender quota or else face financial penalty. The legislation specifies that at least 30 per cent of a party's list of general election 
candidates must be women. If not, funding parties receive from the state under the Electoral Act 1997 will be halved. The quota will apply only to general elections and it is proposed that the threshold will rise to 40 per cent after seven years. The legislation is intended as a modest step towards gender parity in Irish politics. If implemented, Ireland will be the seventh country in the European Union with a legislative gender quota $^{51}$. It is due to come into effect at the next general election. Although it has been welcomed by groups and individuals advocating greater gender equality in political decision-making, a number have argued that the quota should also be applied for elections to other political assemblies, especially for local elections. The minister has so far ruled this out due to the fact given that the state funding parties receive is based on the share of the vote they obtain at the previous general election. However, Minister Hogan has stated that he hopes all parties will replicate the model on a voluntary basis in the 2014 local elections. As has been argued, the scarcity of women representatives in local government prevents the development of a pipeline of potential female candidates for the Dáil, thus making a strong case for the use of positive discrimination measures to be extended to the local level.

Opponents of the quota undermine the meritocratic principles of the candidate selection process. Fears have mounted that women candidates will be selected only on the basis of sex and not on ability. Meritocracy is, however, a highly gendered concept. The selection process favors well-networked individuals, usually with local political experience and a history of party activism. As we have illustrated, men are more likely to possess these qualities than women. A gender quota will cut through the status quo and ensure that party organizations must actively seek out women candidates. But we would argue that it is just one of a number of steps that must be taken for gender equality, particularly to ensure that a diverse range of women are able to become active in party politics. In order for women to organically develop a local platform from which to seek a political career, they must be facilitated to become active party members and to take up leadership positions in the organization. The current lack of women in influential constituency and branch positions may pose further obstacles to achieving gender balance in Irish electoral politics. Research by Galligan revealed a persistent bias in favor of traditional gender roles in internal party structures ${ }^{52}$. Across parties, women account for a higher percentage of those in supportive roles (secretaries and treasurers) than in leadership positions (chairs and vice-chairs). Two positive effects might emerge from an increase in the number of females in local leadership roles. Firstly, women will be more visible to the organization, enhancing their stature as "viable" candidates. Secondly, considering the important role chairs and vice-chairs play in targeting new candidates, women in these positions might be more inclined to use their own networks to find and encourage other women to run. This proposition is illustrated by Canadian research. Tremblay and Pelletier show that more female constituency Canadian party presidents led to measures to encourage women candidates, especially in centre and centre-right parties ${ }^{53}$. In a similar vein, Cheng and Tavits argue that women candidates are more likely to be nominated in ridings where the local party president is female ${ }^{54}$. Both studies show the importance of informal factors in influencing women's participation in electoral politics. This is of particular importance in decentralized selection systems like Ireland. In this light, recruitment drives for new women members, affirmative action for key internal party positions and a candidate gender quota, alongside civic education programs, training, 
mentoring and funding for new candidates, and better childcare facilities, should all be introduced to promote gender balance in political participation in Ireland.

This article has highlighted the challenges that women face in becoming candidates and elected representatives in Ireland. Given their historic and contemporary underrepresentation, the use of a quota mechanism has been advocated to increase the number of women who appear on the ballot. The impending legislation being considered in Ireland replicates a much larger effort seen in many states to implement institutional mechanisms aimed at increasing women's representation ${ }^{55}$. Continuing problems with women being nominated to run for major parties in Irish general elections warrants this attempt to redress the historic imbalance. For the first time, parties will be obliged to actively seek out and recruit female candidates. If they feel that there is a space for them, a candidate quota may also increase the supply of women willing to run. As such, affirmative action targets both the supply and demand of women candidates. Some maintain that quotas undermine the role of democracy in the selection process and that women will be nominated on the basis of sex and not ability. But politics is not a level playing pitch. As we have seen, those with name recognition, networks, time and funds are advantaged from the outset. A quota will address this, but must be used in conjunction with a host of other measures to fully facilitate women's political participation.

Although this article has gone one step further into understanding the candidate selection process from a feminist perspective, much more work is required in this area. Selection conventions should be examined in better detail to discern why women are less likely than men to come through the process successfully. To this end, research should focus on women and men who sought and failed to win a nomination to run for a particular party. Of those in the electoral pipeline, these are the individuals who will best know the barriers that aspirant candidates face. Their views are crucial to a broader understanding of the complex relationship between gender and localism in political party recruitment.

\section{NOTES}

2. Najma Chowdhury, Nancy J. Nelson, Kathryn A. Carver, Nancy J. Johnson, and Paula L. O'Loughlin, "Redefining Politics: Patterns of Women's Political Engagement from a Global Perspective", in Barbara J. Nelson and Najma Chowdhury (eds.), Women and Politics Worldwide, New Haven, Yale University Press, 1994, p. 3-24.

3. For example, see Drude Dahlerup, "The Story of the Theory of Critical Mass", Politics \& Gender, Vol. 2, No. 4, December 2006, p. 511-522; Ian McAllister and Donley T. Studlar, "Does a Critical Mass Exist? A Comparative Analysis of Women's Legislative Representation since 1950", European Journal of Political Research, Vol. 41, No. 2, March 2002, p. 233-253. 
4. For example, see Sarah Childs and Mona Lena Krook, "Should Feminists Give Up on Critical Mass? A Contingent Yes", Politics \& Gender, Vol. 2, No. 4, December 2006, p. 522-530.

5. Jane Mansbridge, "Rethinking Representation", American Political Science Review, Vol. 94, No.4, November 2003, p. 523.

6. Claire McGing, Eimear O'Leary, and Matthew Wall, "The Impact of Gender on the Constituency Roles and Activities of Irish Parliamentarians", Paper Presented at the PSA Women and Politics Biennual Conference: Making a Difference for Women, Bristol, England, February 2012; Pippa Norris, “The Puzzle of Constituency Service”, The Journal of Legislative Studies, Vol. 2, No. 2, Summer 1997, p. 44-46; Lilliard Richardson and Patricia Freeman, "Gender Differences in Constituency Service Among State Legislators", Political Research Quarterly, Vol. 48, No. 1, March 1995, p. 175-176.

7. Sarah Childs, New Labor's Women MPs, Oxon, Routledge, p. 108-123.

8. Fiona Buckley and Claire McGing, "Women and the Election", in Michael Gallagher and Michael Marsh (eds.), How Ireland Voted 2011: The Full Story of Ireland's Earthquake Election, Basingstroke, Palgrave Macmillan, 2011, p. 222.

9. This ranking was made on June 9, 2012. [http://www.ipu.org/wmn-e/world.htm].

10. Vicky Randall, and Ailbhe Smyth, "Bishops and Bailiwicks: Obstacles to Women's Political Participation in Ireland", Economic and Social Review, Vol. 18, No. 3, April 1987, p. 189-214.

11. Ronald Inglehart and Pippa Norris, Rising Tide: Gender Equality and Cultural Change around the World, New York, Cambridge University Press, 2003, p. 127-146 and Pamela Paxton and Sheri Kunovic, "Women's Political Representation: The Importance of Ideology", Social Forces, Vol. 82, No. 1, September 2003, p. 87-114.

12. Dorothy McBridge Stetson, "Gender and European Politics: The Limits of Integration", PS: Political Science \& Politics, Vol. 30, No. 2, June 1997, p. 196.

13. Jane S. Jensen, Women Political Leaders: Breaking the Highest Glass Ceiling, New York, Palgrave Macmillan, 2008, p. 7 and 26; Richard E. Matland, "Women's Representation in National Legislatures: Developed and Developing Countries", Legislative Studies Quarterly, Vol. 23, No. 1, February 1998, p. 109-125; and Alan Siaroff, "Women's Representation in Legislatures and Cabinets in Industrial Democracies", International Political Science Review, Vol. 21, No. 2, April 2000, p. 197-215.

14. Pat O'Connor, "The Irish Patriarchal State: Continuity and Change", in Maura Adshead, Peadar Kirby, and Michelle Millar (eds.), Contesting the State: Lessons from the Irish Case, Manchester: Manchester University Press, 2008, p. 143-164.

15. Daniel Stockemer, “Women's Representation: A Comparison between Europe and the Americas", Politics, Vol. 28, No. 2, May 2008, p. 67.

16. S. O'Sullivan, “Gender and Attitudes to Women's Employment, 1988-2002”, in Betty Hilliard and Máire Nic Ghiolla Phádraig (eds.), Changing Ireland in International Comparison, Dublin, Liffey Press, 2007, p. 136.

17. Phillip O'Connell, "Sick Man or Tigress? The Labor Market in the Republic of Ireland", in Anthony Heath, Richard Breen, and Christopher Whelan (eds.), Ireland North and South: Perspectives from Social Science, Oxford, Oxford University Press, 1999, p. 217.

18. Yvonne Galligan, "Women and Politics", in John Coakley and Michael Gallagher (eds.), Politics in the Republic of Ireland, Basingstroke: Palgrave Macmillan, 2010, p. 274. 
19. See Leslie Schwindt-Bayer, Michael Malecki, and Brian F. Crisp, "Candidate Gender and Electoral Success in Single Transferable Vote Systems", British Journal of Political Science, Vol. 40, No. 3, April 2010, p. 693-709.

20. Fiona Buckley, Neil Collins, and Theresa Reidy, "Ballot Paper Photographs and LowInformation Elections in Ireland", Politics, Vol. 27, No. 3, October 2007, p. 174-181 and Gail McElroy and Michael Marsh, "Candidate Gender and Voter Choice: Analysis from a Multimember Preferential Voting System", Political Research Quarterly, Vol. 63, No. 4, December 2010, p. 822-833.

21. Yvonne Galligan, "STV: A Gender-Proportional System?" in Manon Tremblay (ed.), Women and Legislative Representation, New York, Palgrave Macmillan, 2008, p. 155-156; Yvonne Galligan, Michael Laver, and Gemma Carney, "The Effect of Candidate Gender on Voting in Ireland, 1997", Irish Political Studies, Vol. 14, 1999, p. 118-122; and Leslie A. Schwindt-Bayer, "The Incumbency Disadvantage and Women's Election to Legislative Office", Electoral Studies, Vol. 24, No. 2, June 2005, p. 227-244.

22. Mona Lena Krook, “Women's Representation in Parliament: A Qualitative Comparative Analysis”, Political Studies, Vol. 58, No. 5, December 2010, p. 886-908.

23. Garret Fitzgerald, Reflections on the Irish State, Dublin, Irish Academic Press, 2003, p. 66-67.

24. Gallagher, op. cit.

25. Timothy J. White, "Why So Few Women in Dáil Eireann? The Effects of the Single Transferable Vote Election System", New Hibernia Review, Vol. 10, No. 4, 2006, p. 71-83.

26. Wilma Rule, "Women's Underrepresentation and Electoral Systems", PS: Political Science \& Politics, Vol. 27, No. 4, December 1994, p. 689-692 and Susan Welch and Donley Studlar, "Multi-Member Districts and the Representation of Women: Evidence from Britain and the United States", Journal of Politics, Vol. 52, No. 2, May 1990, p. 391-412.

27. David M. Farrell, Malcolm Mackerras, and Ian McAllister, "Designing Electoral Institutions: STV Systems and their Consequences", Political Studies, Vol. 44, No. 1, March 1996, p. 34.

28. Richard L. Engstrom, "District Magnitudes and the Election of Women to the Irish Dáil", Electoral Studies, Vol. 6, No. 2, August 1987, p. 123-132, p. 238; Richard E. Matland and Donley T. Studlar, "The Contagion of Women Candidates in Single Member District and Proportional Representational Electoral Systems: Canada and Norway", Journal of Politics, Vol. 58, No. 3, August 1996, p. 709; and Pippa Norris, Electoral Engineering: Voting Rules and Political Behavior, New York, Cambridge University Press, 2004, p. 187. This assumption is contested by Galligan, "STV: A Gender-Proportional System?", p. 154-155 who found that constituency size or district magnitude had no consistent effect on female TDs elected from the three largest parties in Ireland from 1948 through 2002.

29. Kira Sanbonmatsu, Where Women Run: Gender and Party in the American States, Ann Arbor, University of Michigan Press, 2006.

30. The need to get more women into the pipeline of Irish politics is explored in Fiona Buckley, Mack Mariani, Claire McGing, and Timothy J. White, "Gender and Candidate Success in the 2011 Irish General Election", Paper Presented at the PSA Women and Politics Biennual Conference: Making a Difference for Women, Bristol, England, February 2012. 
31. Richard L. Fox and Jennifer L. Lawless, "Entering the Arena? Gender and the Decision to Run for Office", American Journal of Political Science, Vol. 48, No. 2, (April 2004), p. 264-280.

32. Liam Weeks, "Candidate Selection: Democratic Centralism or Managed Democracy?", in Michael Gallagher and Michael Marsh (eds.), How Ireland Voted 2007: The Full Story of Ireland's General Election, New York, Palgrave Macmillan, 2007, p. 61.

33. In the Irish context see Gail McElroy and Michael Marsh, "Electing Women to the Dáil: Gender Cues and the Irish Voter”, Irish Political Studies, Vol. 26, No. 4, December 2011, p. 521-534.

34. Jenny Chapman, Politics, Feminism and the Reformation of Gender, London, Routledge, 1993, p. 73-108.

35. Joni Lovenduski, Feminizing Politics, Cambridge, Polity Press, 2005, p. 45-65.

36. Pippa Norris and Joni Lovenduski, Political Recruitment: Gender, Race, and Class in the British Parliament, New York, Cambridge University Press, 1995. There have been some attempts to go beyond this model of candidate recruitment. See Mona Lena Crook, "Beyond Supply and Demand: A Feminist-Institutionalist Theory", Political Research Quarterly, Vol. 63, No. 4, December 2010, p. 707-720.

37. See the various case studies in Michael Gallagher and Michael Marsh (eds.), Candidate Selection in Comparative Perspective: The Secret Garden of Irish Politics, London, Sage Publications, 1988.

38. Buckley and McGing, "Women and the Election", p. 236.

39. Claire McGing, "Gender and the candidate selection process in Ireland", (unpublished paper).

40. Central Statistics Office, National Employment Survey: 2008 and 2009, Dublin, The Stationary Office, p. 7.

41. No study has of yet been dedicated to gender and access to campaign funds in an Irish setting. We believe this to be a fruitful area for future research.

42. National Women's Council of Ireland, Who Cares? [http://www.nwci.ie/download/pdf/ who_cares_october_2009.pdf], accessed 9 January 2012.

43. McGing, "Gender and the candidate selection process in Ireland", unpublished.

44. Sinn Féin had only one contested selection convention and this was between two men. Information for the Green Party was unavailable for most constituencies.

45. Information sourced from e-mail correspondence with one of the authors.

46. [http://www.dublinpeople.com/content/view/4112/57/], accessed 9 January 2012.

47. [ http://www.independent.ie/national-news/elections/latest-news/bitter-split-in-Laborbranch-over-choice-of-candidate-2555836.html], accessed 9 January 2012.

48. Lovenduski, op. cit., p. 90.

49. Ian Dinan, "Exceeding the Quota: A Study of the Implementation by Fine Gael of a Gender Quota in the Town Council Elections", unpublished undergraduate thesis, National University of Ireland, Maynooth.

50. The National Women's Council of Ireland has calculated that it will take approximately 370 years before a 50:50 gender balance is seen in the Dáil. See National Women's Council of Ireland, Irish Politics: Jobs for the Boys! [http://www.nwci.ie/download/ pdf/irpol4.pdf], accessed 9 January 2012. 
51. The other EU countries are Belgium, France, Portugal, Poland, Slovenia and Spain. See [http://www.quotaproject.org/].

52. Galligan, "Women and Politics", op. cit., p. 272.

53. Manon Tremblay \& Rejean Pelletier, "More Women Constituency Party Presidents: A Strategy for Increasing the Number of Women Candidates in Canada?", Party Politics, Vol. 7, No. 2, 2001, p. 157-190.

54. Christine Cheng \& Margit Tavits, "Informal Influences in Selecting Female Political Candidates", Political Research Quarterly, Vol. 64, No. 2, 2011, p. 460-471.

55. Sarah Sunn Bush, "International Politics and the Spread of Quotas for Women in Legislatures”, International Organization, Vol. 65, No. 1, Winter 2011, p. 103-137.

\section{ABSTRACTS}

This article reviews the historic and contemporary challenges to women's electoral representation in Ireland. After summarizing the cultural and institutional obstacles to greater female representation, this article analyzes candidate selection, especially in relation to the 2011 Irish General Election, a process that appears to be the significant hurdle preventing more women from attaining elected office. It also discusses the proposed legislation that uses quotas to ensure the major political parties in Ireland nominate initially at least 30 per cent of their candidates to be women. It is hoped that this measure will redress the historic and chronic underrepresentation of women in Irish electoral politics.

Dans cet article, les auteurs reconsidèrent les défis auxquels les femmes candidates à la représentation électorale ont fait et font encore face en Irlande. Après avoir résumé les obstacles culturels et institutionnels qui s'opposent à une plus grande représentation des femmes, cet article analyse le processus de sélection des candidats notamment lors des élections législatives irlandaises de 2011. Ce processus semble être un obstacle visiblement considérable à l'élection de davantage de femmes. Cet article s'interroge aussi sur la législation qui propose d'imposer des quotas afin de garantir la nomination d'au moins $30 \%$ de femmes au sein des partis politiques principaux d'Irlande. Cette mesure devrait parvenir à résoudre le problème de la sousreprésentation des femmes dans les élections irlandaises.

\section{INDEX}

Mots-clés: femmes - représentation politique, État irlandais (République d'Irlande), partis politiques

Keywords: women - political representation, Irish State (Republic of Ireland), political parties 
AUTHORS

CLAIRE MCGING

Department of Geography, National University of Ireland-Maynooth, Maynooth, Co. Kildare, Ireland 